\section{artelogie}

\section{Artelogie}

Recherche sur les arts, le patrimoine et la littérature de l'Amérique latine

$10 \mid 2017$

Après le paysage : l'art, l'inscription et la représentation de la nature en Amérique latine aujourd'hui

\title{
Entretien avec Jacques Leenhardt. Le voyage pittoresque et historique au Brésil de Jean-Baptiste Debret : un "incunable" des sciences sociales
}

Catalina Valdés et Jacques Leenhardt

\section{OpenEdition}

Journals

Édition électronique

URL : http://journals.openedition.org/artelogie/871

DOI : 10.4000/artelogie.871

ISSN : 2115-6395

Éditeur

Association ESCAL

Référence électronique

Catalina Valdés et Jacques Leenhardt, «Entretien avec Jacques Leenhardt. Le voyage pittoresque et

historique au Brésil de Jean-Baptiste Debret : un "incunable" des sciences sociales », Artelogie [En ligne], 10 | 2017, mis en ligne le 05 avril 2017, consulté le 15 septembre 2020. URL : http:// journals.openedition.org/artelogie/871

Ce document a été généré automatiquement le 15 septembre 2020

Association ESCAL 
Entretien avec Jacques Leenhardt. Le voyage pittoresque et historique au Brésil de Jean-Baptiste Debret : un "incunable" des sciences sociales

Catalina Valdés et Jacques Leenhardt

Ce média ne peut être affiché ici. Veuillez vous reporter à l'édition en ligne http:// journals.openedition.org/artelogie/871 